\title{
14. A Village School
}

Nation (15 Oct. 1966), pp. 5-6.

Written on the blackboard with that neatness of hand practised universally by primary school teachers was the poem:

Goodbye to the roar of the busy street and the dusty pavement that scorches the feet

The holidays are here!

What significance had the poem for the children of Lea Lea where the school ground is the lee slope of a dune with sand soft to ankle depth? The roar of traffic is never heard at Lea Lea: the twenty-three-mile road from Port Moresby ends at the river immediately before the village. Travellers have to leave their cars or trucks under the scattered coconut palms and make their way into the village by one of the outrigger canoes which lie on either bank of the river.

If the poem was alien to the culture of the Motu people, it has not caused them to reject the school. Deputations made by the villagers to the Department of Education in the 1950s were representative of their desire to obtain schools as the means to knowledge and better paid jobs. Before the establishment of the Administration's school, the LMS Mission had conducted classes in Lea Lea; the teacher was the pastor assisted by his wife and children - if they were sufficiently well-educated. The mission only went to standard (grade) 4 , and few students completed the fourth year. The language of instruction was Motu, but some simple English was taught. Sentences such as 'Henao goes to the garden' were read from English primers by the better students. Some of the parents of the present students at the primary school are literate in Motu only. But, of course, apart from 'The New Testament' they possess little written in Motu on which they can demonstrate their literacy.

The mission did not resent the establishment of the Primary T School, - the ' $\mathrm{T}$ ' standing for Territory, indicating that the school follows a Territory-oriented syllabus as opposed to some of the schools in the town which follow 'A' or New South Wales courses. From a total village population of approximately 700, it has 179 students, the enrolment being slightly inflated by students from the neighbouring village of Papa. In some age groups there would be close enough to one hundred per cent attendance at school. Only five grades are being taught in 1966, standards one, two, four, five and six. The preparatory class and standard three had to be abandoned because there were neither teachers nor classrooms available. 


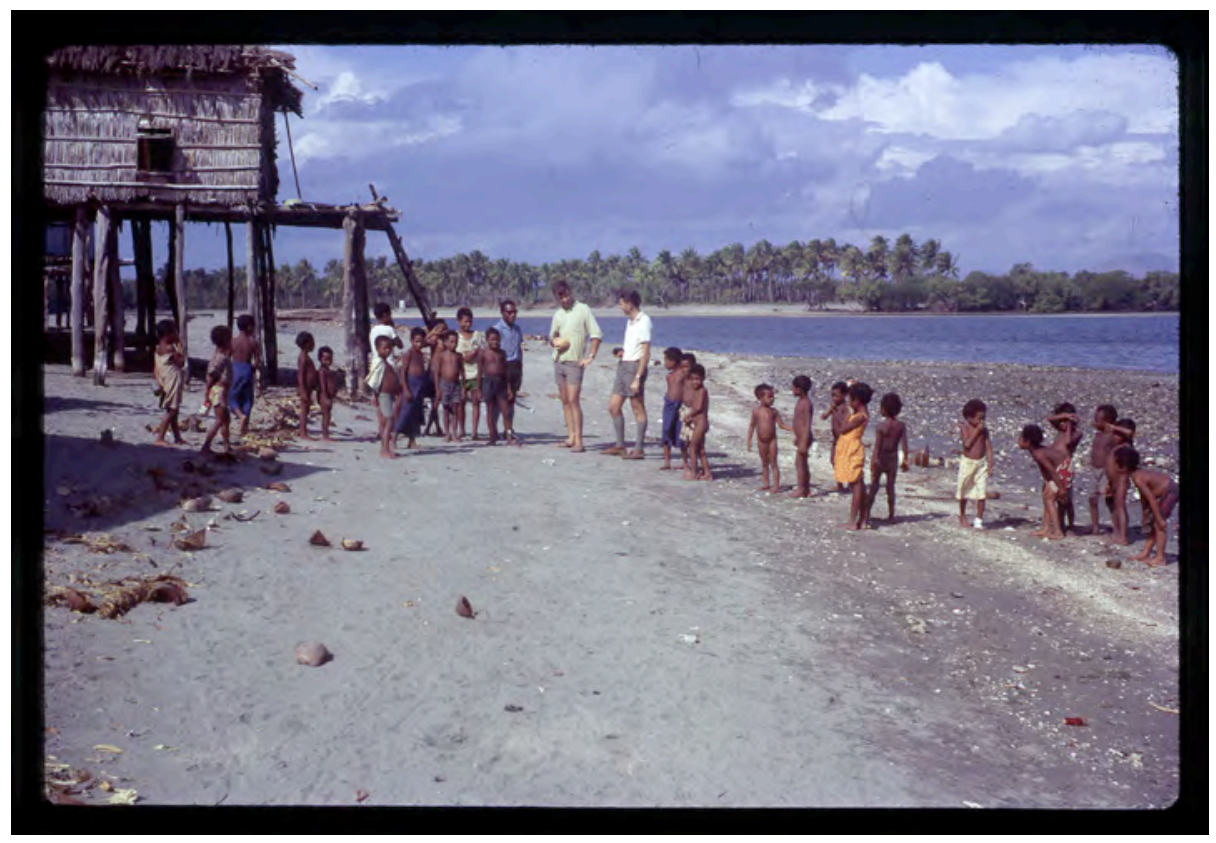

Figure 3: Hank Nelson (holding camera) at Lea Lea Village, 12 August 1966. Bill Gammage (holding a green coconut) is left of him, then Ratu from Rabaul, a Primary T School teacher at Lea Lea, and his wife, also a teacher, from Lea Lea.

Source: Photo by Chris Gammage, provided by Pacific Manuscripts Bureau, Canberra, PMB photo 46-097.

What opportunities will be open to the thirty-three students completing standard six at the end of the year? Perhaps ten will go on to higher education at Sogeri Secondary School (a boarding school for boys) or at Kwikila (a coeducational boarding school). Another handful might find places at Idubada Technical School or at some other vocational training centre. Few of the girls will have any opportunity to continue their education. Generally the villagers are reluctant to allow their daughters to wander among strange men at distant boarding schools; and some parents are anxious to have their girls earn a cash wage as soon as possible.

For those who remain in the village, the chances of entering the cash economy are limited. When orders for wood are received, bundles are cut and sold in Port Moresby to the Papuan householders who depend on wood for fuel. Some fish, shell-fish and crabs, also, can be sold in Port Moresby. There is little possibility of developing cash cropping in the sandy soil, low rainfall conditions of Lea Lea. Cattle could be grazed on the land at the back of the village - land traditionally used for hunting - for the country is covered in coarse grass, is only slightly undulating, and is lightly timbered. That cattle can be run is demonstrated on 
the nearby Steamships Trading Co. lease. A cattle industry requires skills and capital. The skills could be acquired, but in a community which at present lacks the funds to run a motor vehicle, the accumulation of finance to purchase stock and run a fence will be a long task.

For some time to come the basic means of entry to the cash economy for the villagers will be through employment in Port Moresby. The construction industries in particular offer opportunities for the men. Lea Lea has disadvantages for the commuter. The two trucks which leave each day for Port Moresby charge three shillings for a one-way fare, to the fifty or so daily travellers. For a workman receiving perhaps ten dollars a week, sixty cents represents a high percentage of his earnings. The cost of fares largely explains the absence of women travellers. Girls in wage employment (frequently as shop-assistants) live in employers' hostels in Port Moresby.

The trucks are run by the Pako brothers, sometimes referred to as the only Motu entrepreneurs. It seems unlikely that the villagers will be able to purchase a truck of their own in the near future, although by their donations of ten dollars per person, the villagers raise approximately 6,000 dollars a year for the church.

The newcomer to the Territory who receives perhaps ten or twenty requests for a job from hopeful 'houseboys' is immediately aware that he is in a country with an excess of population demanding urban employment. Even more depressing are the figures given by the World Bank report on New Guinea: it gives a figure of 80,000 indigenes in employment in 1963, an increase of 10,000 over the past decade. Relative to the total number employed that growth rate may be reasonable: seen against a population increasing at about three per cent p.a. it means a consistent decline in the proportion of the population in wage labour.

It has become a cliché to speak of New Guinea as a land of villages; but it is against a background of innumerable villages like Lea Lea, some with superior resources, some with inferior, that the problem must be seen. Half of the children from the villages have no schools to attend. Inevitably the villages without schools see the first step towards meeting their rising expectations to be the opening of educational opportunities for their children. The questions put by Mr Sinake Giregire (Goroka) on the first day of the recently completed ninth meeting of the House of Assembly were representative of a number of similar demands:

Is it intended to establish a primary school in the Yonki area in the Eastern Highlands district?

If so, when?

If not, why not? 
And the reply given by Mr FC Henderson, the Assistant Administrator (Economic Affairs), did not contain any heartening euphemism which could be taken back to the voters.

Mr Henderson: The answer to the Honourable Member's question is as follows:

A primary school will be established in the Yonki area of the Eastern Highlands District.

Not in the foreseeable future.

Lack of trained teachers and insufficient funds.

Later in the session John Guise summarised the demand for education: 'There is a shortage of teachers and I think that every member coming here, including myself, will always ask for teachers. This pressure is coming from the people and also from local government councils everywhere'.

The Administration's policy, as Mr Henderson made clear, no longer aims for universal literacy in the immediate future. Rather than dissipate limited resources in the dispersal of education, funds are being directed towards the previously neglected secondary and tertiary levels of training. Resistance to the Administration's policy is apparent in two areas - from those places at present without government primary schools and from villages (like Lea Lea) where there are still inadequate opportunities for students leaving the primary $\mathrm{T}$ schools. 'Balanced development' in education is desirable as long as you don't live in one of those areas which have to be neglected to create 'balance'.

It has been said that the revolutions in the African States were revolutions of school teachers. Being an educated and urban class, they have not always been content to work in the villages on relatively low wages. There was no evidence of intense dissatisfaction likely to lead to militant action among the five staff members at Lea Lea. Satu, the fifth grade teacher, originally from Rabual, married a local girl and stayed on in the village. One of the other teachers also came from outside the Central District, and the apparent acceptance of the two outsiders by the villagers may be evidence against the fears of regional and tribal fraction fighting in an independent Papua New Guinea. The housing provided for the staff by the Administration - except for the small aluminium house provided for the headmaster - is not greatly superior to the general level of village dwelling. Relative to Australian standards (admittedly an unfair comparison), the staff were not well educated. Satu, for example, had completed standard nine before doing a one year teacher's college course. He is currently attempting to improve his qualifications by taking a Queensland correspondence course. 
The economic basis of life in Lea Lea will be changed very slowly. The value of Territory exports might be rising, but the figures reflect little change in the majority of the villages. The capacity of the schools to open wider opportunities is limited. But the aspirations of the village people for education and ultimately for a greater share in the cash economy, are rising fast. The crucial thing will be the political effects of frustrated villagers demanding more opportunities for entry into the glittering cash economy. 
This text taken from The Boy from Boort: Remembering Hank Nelson, Edited by Bill Gammage, Brij V. Lal, Gavan Daws, published 2014 by ANU Press, The Australian National University, Canberra, Australia. 